\title{
Effect of polythene pot thickness on seedling growth of Chrysophyllum albidum G. Don (Ericales: Sapotaceae)
}

\section{0. 0jo* and T. Adeniran}

Federal College of Forestry. P.M.B. 5054 Ibaban. Oyo State. Nigeria. *Email: ojobamideleakure@yahoo.com.

\begin{abstract}
The study investigated the response of tree seedlings to different pot thickness. Chrysophyllum albidum G. Don (Ericales: Sapotaceae) seedlings were subjected to four treatments, $\mathrm{T} 1=0.01 \mathrm{~mm}$ pot polythene thickness, $\mathrm{T} 2=0.02$ $\mathrm{mm}$ polythene pot thickness, $\mathrm{T} 3=0.03 \mathrm{~mm}$ polythene pot thickness, $\mathrm{T} 4=0.04 \mathrm{~mm}$ pot polythene thickness, $0.01 \mathrm{~mm}$ served as control. There were four treatments replicated five times making a total of twenty seedlings altogether. The experiment was arranged in Randomized Complete Block Design (RCBD). Growth parameters assessed fortnightly were plant height $(\mathrm{cm})$, stem diameter $(\mathrm{mm})$ and number of leaves. Soil temperature of each treatment at different time intervals were also monitored and recorded. Data recorded were analyzed using descriptive statistics and analysis of variance (ANOVA). The result showed that $\mathrm{T}_{1}$ had the best performance in terms of plant height and stem diameter while equal number of leaves were recorded in all the treatments. Analysis of variance (ANOVA) showed that there were no significant differences among treatments at $5 \%$ level of significance. This indicates that polythene pot thickness of $0.01 \mathrm{~mm}-0.04 \mathrm{~mm}$ can be used to raise $C$. albidum seedlings at the nursery stage. Soil temperature increases with polythene pot thickness. Hence, $\mathrm{T}_{4}$ gave the highest soil temperature of $36.7{ }^{\circ} \mathrm{C}$. Soil temperature and seedlings growth increases with polythene pots thickness. For optimum growth and development of $C$. albidum seedlings in the nursery $0.01 \mathrm{~mm}$ polythene pot should be used.
\end{abstract}

Keywords: Chrysophyllum albidum seedlings; Agbalumo; Udala; African star apple; Polythene thickness; Soil temperature.
Received

May 6, 2019

Accepted

July 28, 2019

Available online

July 30, 2019

Released

August 31, 2019

Full Text Article

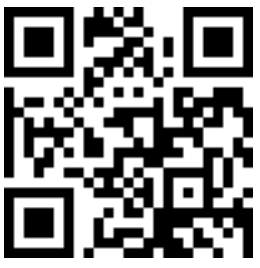

\footnotetext{
ORCID

(1) $0000-0003-0750-4431$ M. O. Ojo

(ㄱ) 0000-0002-4080-3663 T. Adeniran
}

\section{Introduction}

According to Josiah et al. (1992), in tropical countries the containers system used in seedlings production is vastly different. The common system over most Africa, Latin America, and South East Asia is a container system that utilizes a black bag called polythene pot.
This is literally a polythene pot of $1 \mathrm{~mm}$ with greater thickness of one or two small holes punched in the bottom for drainage and aeration.

Several experiments (Jones, 1993; Rabendrum and Jeyasingam, 1996; Dun et al., 1997) have been concluded to identify the effect of different container on the tree seedlings of tropical tree 
species but none of the published data considered the effect of polythene pot thickness on the growth of tree seedlings. Though seedlings are easily grown in any container (Jaenicke, 1999), there is need to consider the effect of container size, shape and thickness on the early growth of tree seedlings, hence, the need to select a rapidly available container of suitable thickness which will produce high quality seedlings at the lowest cost (Gera et al., 1996).

The use of polythene pot in tree seedlings production is cheap with suitable manual for operation. It does not require special support structure and contain more soil with greater water and nutrient holding capacity. It has the following disadvantages, poor nutritional status and poor aeration of the medium, limited fibrousity, root coiling (Annapurna, 2004), Miller and Jones, (1995) also reported that polythene bags filled with soil may produce seedlings with good shoot development but poor root system.

Chrysophyllum albidum G. Don (Ericales: Sapotaceae) is one of the fruit producing tree, very popular in the area of construction and for traditional medicine, and it is well known among many people in lowland rainforest zone of Nigeria. It is mostly found in the South-Western part of the country. In the Eastern and Southern parts of Nigeria this tree is called Udala, and amongst the Yoruba of Nigeria, it is called Agbalumo. The full potential of this tree is yet to be discovered, different communities or culture has different impression about it. Economically, some people use its fruits as edible food, while in South Cameroun the seed is used to form cooking oil as the substitute for that of wild mango; others use its stem and branches as fuel wood (Onyekwelu and Stimm, 2014).

According to George et al. (2018), the fleshy fruit pulp is suitable for jams and eaten especially as snacks by both young and old. Besides, $C$. albidum plant parts have been used in folk medicine. Houessou et al. (2012) had also reported that the bark of the species was the most used part. The bark was used against cough, icterus and yellow fever. In southern Nigeria, the bark has also been used to treat malaria while the leaves were used as emollient, fertilizer and for the treatment of skin eruptions, stomach ache and diarrhea (Adewusi, 1997). Okunomo and Egho (2010), also confirmed that the fruits are used in traditional gynecology to treat sterility and sexual weakness. In addition, the seeds are source of oil which is used for diverse purposes. It has been established as a source of natural antioxidant to promote health by acting against oxidative stress in related diseases such as diabetes, cancer and coronary heart diseases (Buritis and Brucar, 2002).

The fruit pulp has been reported to contain significant amount of of ascorbic acid (Adepoju and Adeniji, 2012), vitamins, iron and food (Hostettmann et al., 2000) flavours (Adisa, 2000), fat (Christopher and Miranda, 2011), carbohydrate and mineral elements (Ureigho, 2010). In some African countries, the sticky latex is used as a bird line for catching birds, the seeds also being sources of oil for soap making and other purposes (Bada, 1997) and (Hostettmann et al., 2000). The species also protects the soil against erosion by serving as windbreaks, intercepting rainfall and reducing rainfall and rain splash (Nnadi and Anyanwu, 2018).

Though much study has been carried on the seedlings and its medicinal, environmental and economic benefits, information on the effect of varying polythene pot thickness on the growth of it's seedlings are scarce, this research is thereby conducted to fill this identified gap in knowledge to enhance the effort of foresters, nursery workers, agro-climatologist and silviculturists in raising healthy and climate change adapted species of $C$. albidum at the nursery stage. Findings will be used as yardstick to justify the probable negative 
and positive effect of exposing C. albidum seedlings to varying polythene thickness.

The objectives of the paper are to determine the optimum polythene pot thickness for raising the seedlings at nursery stage and recommend the most suitable thickness for seedling growth and establishment.

\section{Method}

\section{Experimental site}

The experiment was carried out at the nursery of Federal College of Forestry, Ibadan. The college is situated at Jericho Quarters under Ibadan North West Local Government Area of Oyo State, Nigeria. The area lies between latitude $7^{\circ} 26^{\prime} \mathrm{N}$ and longitude $3^{\circ} 36^{\prime} \mathrm{E}$. the climate is tropically dominated by rainfall pattern ranging between 1,400 $\mathrm{mm}-1,500 \mathrm{~mm}$ the average temperature is about $31.2{ }^{\circ} \mathrm{C}$ and relative humidity is about $65 \%$. The eco-climate of the area is rainfall with two distinct seasons which are dry season, usually commencing from November to March and raining season from April to October (FRIN, 2018).

\section{Experimental Design}

C albidum seedlings were collected from the seed store of Forestry Research Institute of Nigeria and were tested for viability before sowing inside a germination box which was filled with washed and sterilized river sand. Watering was done daily and adequately to enhance germination. After three weeks of germination, healthy seedlings of uniform size (plant height, stem diameter, number of leaves) were transplanted into polythene bags of different thickness filled with $2 \mathrm{~kg}$ of top soil. Soil samples were collected from the College Arboretum. There were four levels of treatments replicated five times. The experiment covered fifteen weeks of thorough observation and assessment of growth parameters. Silvicultural treatments like watering, weeding were carried out regularly. Soil thermometer was installed into different containers at $15 \mathrm{~cm}$ depth and monitored.

Growth parameters, such as plant height $(\mathrm{cm})$, stem diameter $(\mathrm{mm})$, and number of leaves, of each seedling in each container were assessed. Initial readings were taken immediately while subsequent ones were taken fortnightly. The study was laid out in a Randomized Complete Block Design (RCBD).

\section{Data analysis}

Descriptive statistical tools were used to compare the treat ment means in each of the parameters assessed while analysis of variances (ANOVA) was used to test the level of significance among different treatments at $5 \%$ probability levels. Least Significant Difference (LSD) was used to separate the means.

\section{Results and discussion}

From Table 1, seedlings planted in $0.01 \mathrm{~mm}$ polythene pot thickness produced the highest mean plant height $(13.08 \mathrm{~cm})$ at the lowest soil temperature of $34^{\circ} \mathrm{C}$. This was followed by $0.02 \mathrm{~mm}(12.01 \mathrm{~cm}), 0.03 \mathrm{~mm}$ $(11.01 \mathrm{~cm})$, and $0.04 \mathrm{~mm}(9.38 \mathrm{~cm})$. In terms of stem diameter, seedlings in polythene pot of $0.01 \mathrm{~mm}$ thickness also recorded the highest mean values of $0.19 \mathrm{~mm}$, followed by polythene pot of $0.02 \mathrm{~mm}$ thickness and $0.03 \mathrm{~mm}$ with the same mean values of $0.18 \mathrm{~mm}$. Polythene pot of $0.04 \mathrm{~mm}$ thickness recorded the lowest mean value of $0.17 \mathrm{~mm}$. However, the same values were recorded for number of leaves in all the treatments. It was observed that soil temperature readings increased with polythene pots thickness. This conforms with the findings of Helaly et al. (2017) who reported increase in soil temperature and more efficient use of soil nutrients with the use of polythene plastic materials for seedling production of Physalis pubescens. Increase in the value of the growth parameters assessed in this study also improved the vegetative growth of $C$. albidum which might have 
contributed to increase in the rate of photosynthesis resulting in better performance.

Seedlings of $C$. albidum performed best at the soil temperature of $34{ }^{\circ} \mathrm{C}$ this is in agreement with Jaenicke, (1999) who reported that the optimum temperature for plant development is between $25^{\circ} \mathrm{C}$ and $35^{\circ} \mathrm{C}$ while any temperature beyond this may have negative effect on the seedlings. However this is contrary to the findings of Reginato et al. (2019) who conducted a research on Gala apples at temperatures between $34^{\circ} \mathrm{C}$ and $38^{\circ} \mathrm{C}$ but discovered that yield and fruit size depended on the maximum temperature.

Table 1. Effect of treatments on mean plant height (PH), stem diameter (SD) and number of leaves (NL).

\begin{tabular}{|l|c|c|c|c|}
\hline Treatment soil & Temp. $\left({ }^{\mathbf{O}} \mathbf{C}\right)$ & PH $(\mathbf{c m})$ & SD $(\mathbf{m m})$ & NL \\
\hline T1 & 34.00 & 13.08 & 0.19 & 5 \\
\hline T2 & 34.60 & 12.01 & 0.18 & 5 \\
\hline T3 & 35.10 & 11.01 & 0.18 & 5 \\
\hline T4 & 36.70 & 9.38 & 0.17 & 5 \\
\hline
\end{tabular}

From Table 2, there were no significant differences among treatments at $\mathrm{p}<0.05$. Hence, any of the polythene pots thickness $(0.01 \mathrm{~mm}-0.04 \mathrm{~mm})$ can be used to raise $C$. albidum seedlings at the nursery stage this is in consonance with the work of (Gera et al., 2000) on Albizia lebbeck though $0.01 \mathrm{~mm}$ thickness is preferable especially when plant height, stem diameter and leaf production are the focus (Singh, 2003). Also the findings from this study is in consonance with Nabieu (2017), who stated that using appropriate polythene bag enhanced aeration to seedling root zones and also provide better seedling establishment of root in the soil region. He advocated the use of appropriate polythene bag which will invariably lead to more leaf production and other growth parameters which are important variables that bestow vigour on seedlings and thus enable them withstand transplanting shock on the field.

Table 2. ANOVA table for seedlings height.

\begin{tabular}{|l|c|c|c|c|c|c|}
\hline SV & DF & SS & MS & F-Cal & F-tab (p < 0.05) & Remark \\
\hline Treatments & 3 & 39.77 & 13.26 & 0.5844 & 3.239 & Ns \\
\hline Error & 16 & 363.02 & 22.69 & & & \\
\hline Total & 19 & 402.79 & & & & \\
\hline
\end{tabular}

Ns $=$ Not significant at $5 \%$ level of significance.

Table 3. ANOVA table for stem diameter.

\begin{tabular}{|l|c|c|c|c|c|c|}
\hline SV & DF & SS & MS & F-Cal & F-tab (p < 0.05) & Remark \\
\hline Treatments & 3 & 0.01 & 0.003 & 0.2308 & 3.239 & Ns \\
\hline Error & 16 & 0.21 & 0.013 & & & \\
\hline Total & 19 & 0.22 & & & & \\
\hline
\end{tabular}

Ns $=$ Not significant at $5 \%$ level of significance. 
The analysis of variance of Table 3 indicated that there were no significant differences among treatments at $\mathrm{p}<0.05$. Hence, any of the polythene pots thickness $(0.01 \mathrm{~mm}-0.04 \mathrm{~mm})$ can be used to raise $C$. albidum seedlings at the nursery stage (Adu-Berko et al., 2011). Nunez and Osborne (2014) also had similar observations with seedlings of Senecio cineraria where seedlings raised in potting container with medium temperature had faster and healthier growth and recommended raising the seedlings in containers though $0.01 \mathrm{~mm}$ thickness performed best in all the parameters assessed.

Table 4. ANOVA table for number of leaves.

\begin{tabular}{|l|c|c|c|c|c|c|}
\hline SV & DF & SS & MS & F-Cal & F-tab (p < 0.05) & Remark \\
\hline Treatments & 3 & 1.16 & 0.39 & 0.0479 & 3.239 & Ns \\
\hline Error & 16 & 130.43 & 8.15 & & & \\
\hline Total & 19 & 131.59 & & & & \\
\hline
\end{tabular}

Ns = Not significant at $5 \%$ level of significance.

From Table 4 there were no significant differences among treatments at $\mathrm{p}<0.05$. Hence, any of the polythene pots thickness $(0.01 \mathrm{~mm}-0.04 \mathrm{~mm})$ can be used to raise $C$. albidum seedlings at the nursery stage. Haldankar et al. (2014) had also noted that raising seedlings in polythene bags improve survival and minimizes transplanting shock during field planting. Singh et al. (1985) reported consistent concomitant increase in growth parameters of Eucalptus hybrid with increase in thickness of polythene bags.

\section{Conclusion}

From the study carried out and based on the result of the statistical analysis, it has clearly shown that $C$. albidum seedlings responded positively to polythene pots of varying thickness in terms of plant height, stem diameter and number of leaves. It was observed that soil temperature readings increased with polythene pots thickness and temperature of $34^{\circ} \mathrm{C}$ favored growth and development of $C$. albidum any temperature beyond this may have adverse effect on seedling growth. The fact that the result of the analysis of variance were not significant with respect to plant height, stem diameter and number of leaves, is an indication that any of the polythene pots of 0.01 $\mathrm{mm}-0.04 \mathrm{~mm}$ thickness can be used to raise $C$. albidum seedlings at the nursery stage.

Having observed that C. albidum seedlings responded positively to all the polythene pots thickness, the polythene thickness ranging from $0.01 \mathrm{~mm}-0.04$ $\mathrm{mm}$ is recommended for optimum growth and development of $C$. albidum seedlings at the nursery stage while the most preferable soil temperature should fall between $30{ }^{\circ} \mathrm{C}-34^{\circ} \mathrm{C}$.

\section{Conflicts of interest}

Authors declare that they have no conflict of interests.

\section{Reference}

Adepoju, 0.; Adeniji, T.P. 0. Nutrient composition and micronutrient potential of three widly grown varieties of African star apple (Chrysophyllum albidum) from Nigeria. African Journal of Food Science, v. 6, p. 344-351, 2012. 
Adewusi, H. A. The African star apple Chrysophyllum albidum indigenous knowledge i.k from Ibadan, South Western Nigeria. In: Denton, O. A.; Ladipo, D. O.; Adetoro, M. A.; Sarumi, M. B. (Eds). Proceedings of a National Workshop on the Potentials of Star Apple in Nigeria. Ibadan, Nigeria: CENRAD, 1997. p. 25-33.

Adisa, S. A. Vitamin C protein and mineral content of African star apple (Chrysophyllum albidum). Proceedings of the 18th Annual Conference of NIST, p. 141-146, 2000.

Adu-Berko, F.; Idun, I. A.; Amoah, F. M. Influence of the size of nursery bags on the growth and development of cashew (Anacardium occidentale) seedling. American Journal of Experimental Agriculture, v. 1, no. 4, p. 440-441, 2011.

Annapurna, D.; Rathore, T. S.; Geeta, J. Effect of container type and size on the growth and quality of seedlings of Indian sandalwood (Santhahim album L.). Australian Forestry, v. 67, n. 2, p. 82-87, 2004.

Bada S. O. preliminary binformation on nthe ecology of Chrysophyllum albidum in west and central Africa. In: Denton, O. A.; Ladipo, D. 0.; Adetoro, M. A.; Sarumi, M. B. (Eds.). Proceedings of a National Workshop on the Potentials of Star Apple in Nigeria. Ibadan, Nigeria: CENRAD, 1997. p 16-25.

Buritis, B. Studies on mineral nutrition of Gambaya albidum. Ibadan: Department of Forest Resources Management, University of Ibadan, 2002. (M. Sc. thesis).

Christopher, E. A.; Miranda, I. D. Chemical evaluation of proximate composition, ascorbic acid and anti-nutrients content of African star apple (Chrysophyllum albidum) fruit. International Journal of Research and Reviews in Applied Sciences, v. 9, no. 1, p 17-46, 2011.

Dun, G. M.; Hutch, J. R.; Lawtey, M. J. Coating nursery container with copper carbonate improve root morphology of five native Australian tree species used in Agro Forestry System. Agroforestry System, v. 37, no. 2, p. $143-155,1997$. https://doi.org/10.1023/ A:1005863707277

FRIN - Forestry Research Institute of Nigeria. Annual meteorological report. Ibadan: FRIN, 2013.
George, O. A.; Adenipekun, E. O.; Fasogbon, S. A.; Oparanozie, J.A. Antimicrobial activities of Chrysophyllum albidum leaves, fruits and seeds. American Journal of Biomedical Sciences, v. 10, no. 1, p. 28-44, 2018. https://doi.org/10.5099/aj18010 0028

Gera, M.; Gera, N.; Bhandari, A. S.; Pant, N. C. Improved seedling quality of polybag plants of Albizia procera: Use of mounted angle iron beds. Indian Forester, v. 126, no. 9, p. 943-947, 2000.

Gera, M.; Sharma, S.; Bhandari, A. S.; Srivastava, R. L. A trial on improved polybag seedlings production system. Indian Forester, v. 122, no. 11, p. 992-998, 1996.

Haldankar, P. M.; Parulekar, Y. R.; Kulkarni, M. M.; Lawande, K. E. Effect of size of polythene bag on survival and growth of Mango grafts. Journal of Plant Studies, v. 3, no. 1, p. 91-95 2014.

Helaly, A. A.; Goda, Y.; El-Rahim, A. A.; Mohammed, A. A.; El-Zeiny, O. A. H. Effect of polythene mulching type on the growth, yield and fruit quality of Physalis pubescens. Advances in Plants Agriculture Research, v. 6 , no. 5, p. 154-160, 2017.

Hostettmann, K.; Marston, A.; Ndjoko, K.; Wolfender, J.-L. The potential of African plants as a source of drugs. Current Organic Chemistry, v. 4, n. 10, p. 973-1010, 2000. https://doi.org/10.2174/1385272003375923

Houessou, L. G.; Lougbegnon, T. O.; Gbesso, F. G. H.; Anagonou, L. E. S.; Sinsin, B. Ethnobotanical study of the African star apple Chrysophyllum albidum G. Don in the Southern Benin (West Africa). Journal of Ethnobiology and Ethnomedicine, 8:40, 2012. https://doi.org/10.1186/1746-42698-40

Jaenicke, H. Good tree nursery practices: Practical guidelines for research nurseries. Nairob: ICRAF, 1999.

Jones, S. J. Essential of good planting. Stock, Forest and Forest Technician Bulletin, no. 2, p. 1-7, 1993.

Josiah, S. J.; Jones, N. Root trainers in seedlings production system for tropical forestry and agro forestry. Washington DC, USA: World Bank Asia, Technical Department, Agricultural Division, 1992. 
Miller, J. H.; Jones, N. Organic compost-based growing media for tree seedling nurseries. World Bank Technical Paper, n. 264, p. 75, 1995.

Nabieu, P. The effect of size of polythene on cocoa seedlings establishment in the nursery. Liberian Agricultural Forestry and Environment Blog, 2017. Available from: $<$ https://lafeb.co.network/the-effect-of-sizeof-polythene-on-cocoa-seedlingestablishment-in-the-nursery/>. Accessed on: Jan. 21, 2019.

Nnadi,P.; Anyanwu, D. I. Effect of extraction method soil media on germination and seedling establishment of Chrsophyllum albidum. International Journal of Horticulture and Forestry Research, v. 2, n. 1, p. 1-11. 2018.

Nunez, G.; Osborne, R. K. The effects of potting container size and irrigation frequency on medium temperature. Proceedings of the International Plant Propagator Society, v. 64, p. 171, 2014.

Okunomo, K.; Egho, E. O. Economic importance of some underexploited tree species in Nigeria: Urgent need for separate research centers. Continental Journal of Biological Sciences, v. 3, p. 16-32, 2010.

Onyekwelu, J. C.; Stimm, B. Chrysophyllum albidum. Enzyklopädie der Holzgewächse: Handbuch und Atlas der Dendrologie, 2011. https://doi.org/10.1002/97835276 78518.ehg2011015
Rabendrum, N.; Jeyasingam, K . The effect of pot size and mulch on planting stock of exotic and indigenous species in Sri Lanka. In: Yapa, A. E. (Ed.). Proceedings of the International Symposium on Recent Advances in Tropical Tree Seed Technology and Planting Stock Production. Muak-Lek, Saraburi, Thailand, ASEAN Forest Tree Centre, p. 119-125, 1996.

Reginato, G.; Mesa, K.; Riquelme, C. Fruit size and yield efficiency of Gala apples grown in Chile depend on winter temperatures and season length. European Journal of Horticultural Science, v. 84, no. 3, p. 124130, 2019.

Singh, A. Fruit physiology and production. 5. ed. Ludhiana: Kalyani Publishers, 2003.

Singh, P.; Agnihotri, Y.; Mittal, S. P.; Mishra, P. R. Optimum size and thickness of polythene bags for raising nursery of Eucalptus hybrid. The Indian Forester, v. 111, n. 5, p. 318-327, 1985.

Ureigho, U. N. Nutrient values of Chrysophyllum albidum Linn. African star apple as a domestic income plantation species. African Research, n. 4, p. 50-56, 2010. 